\title{
Indoor Air Quality and Thermal Comfort Assessment of Two Portuguese Secondary Schools: Main Results
}

\author{
Luísa Dias Pereira ${ }^{1}$, Luis Neto ${ }^{1,2}$, Manuel Gameiro da Silva ${ }^{3}$, \\ ${ }^{1,3}$ ADAI,LAETA - University of Coimbra, ${ }^{2}$ Instituto Politécnico de Castelo Branco
}

\begin{abstract}
The results of the field study about indoor thermal comfort in two of the involved schools of the 3Es project are presented. The thermal comfort and indoor air quality assessment was conducted by monitoring physical parameters and survey questionnaires. The subjective assessment shows that the students found temperature range beyond the comfort zone acceptable, and revealed the occupants' accommodation to $\mathrm{CO}_{2}$ exposure. The $\mathrm{CO}_{2}$ exceeding values exposed that IAQ is a problem and action should be taken to promote $\mathrm{CO}_{2}$ dilution when HVAC systems are not active.
\end{abstract}

Keywords - Indoor air quality, thermal comfort, school, TSV/PD.

\section{INTRODUCTION}

A major rehabilitation and refurbishment program of secondary school buildings has been carried out in the last few years in Portugal - Modernising Secondary Schools in Portugal [1]. "The program has the ambition to tackle the physical deterioration of the building stock in terms of energy performance and environmental standards, addressing environmental comfort, sanitary standards and the functional adequacy of the buildings for teaching and learning, often with extension of the existing built area» [2] cited in [3].

The indoor environmental quality (IEQ) in school environments is very important. Firstly, children are particularly sensitive to a poor indoor environment. Secondly, they are physically still developing and in comparison to adults will suffer the consequences of a poor indoor environment earlier [4]. Poor indoor air quality (IAQ) is a worldwide problem. In the US, the General Accounting Office found more than 15,000 schools suffering from poor IAQ (1995' data) [5]. This problem has also been verified in the European countries [6]. Students' and teachers' performance under poor IAQ conditions have been recently explored [7], [8] and a notably increased student absenteeism has been verified as a consequence. For a proper learning environment, school buildings require proper indoor comfort conditions, including thermal comfort, indoor air quality (IAQ), adequate lighting conditions and a quiet atmosphere.

The work present herein was developed in the context of a research project called Energy Efficient Schools (Escolas Energeticamente Eficientes - 3Es) [9].

\section{METHOD AND OBJECTS OF STUDY}

The results of the field study about indoor thermal comfort in two of the involved schools of the $3 E s$ project are herein presented. Both of the field surveys were carried out in the East and South-East region of the Portuguese mainland territory.
Aiming at addressing indoor comfort quality (ICQ) both thermal comfort (TC) and IAQ condition were surveyed, through an on-site campaign, divided into two main stages: a) short-term measurement of physical parameters (air temperature and relative humidity) and the monitoring of $\mathrm{CO}_{2}$ concentrations; b) IEQ subjective assessment through a survey conducted among the students. The full methodology was previously presented in [10].

The measurements and questionnaires were carried out during the mid-season, for a two-week period from the end of April until mid-May 2013. Outdoor air temperature values were registered hourly at the nearest climatological station.

All data were collected inside two classrooms with different solar orientation in each of the schools. The study herein presented focuses on the south-oriented classrooms of each school.

\section{A. Case studies description}

The schools currently under study are located 85 and $165 \mathrm{~km}$ from the oceanic line coast, $255 \mathrm{~m}$ and $475 \mathrm{~m}$ respectively above the sea level, in the climatic zones W1S3 and W1S3 (Winter 1, Summer 3) [2] - the number of heating degree days (HHD) of the schools are 1,145 and 1,496 (according to the climatic zones for the heating and cooling seasons of the 2013 revised legislation (in Portugal the reference value for HDD calculation is $18^{\circ} \mathrm{C}$ ) [11], [12], including the schools' precise location, including altitude variation), as indicated in Fig. 1.

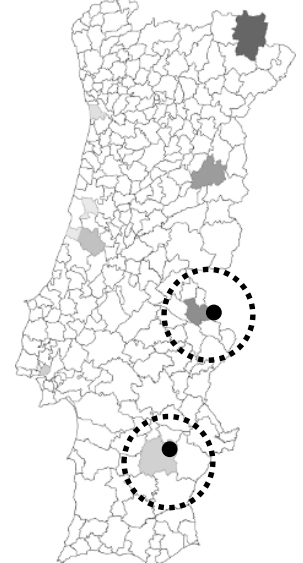

Fig. 1. Map of Portugal highlighting the 8 schools' selection (CCD location) of the 3 Es project [9]. The dotted circles indicate the municipalities of the two schools presented in this work, which in turn are marked with the black dot.

Both schools are located in the Mediterranean climate region, which is characterized by dry summers and moderate winters. Average monthly temperatures are sometimes quite high, over $35^{\circ} \mathrm{C}$ in the summer, and in winter, average monthly mean 
temperatures (AMM) normally do not go below $10^{\circ} \mathrm{C}$. The winter in Portalegre is harsher than in Beja - temperatures can go under $0^{\circ} \mathrm{C}$ - this is easily confirmed by the HDD difference between the two schools. Fig. 2 exposes this climate similarity. The annual thermal amplitude is moderate. In terms of rainfall, the total annual value is low (around $570 \mathrm{~mm}$ in Beja and $850 \mathrm{~mm}$ in Portalegre) and it occurs mostly in winter.

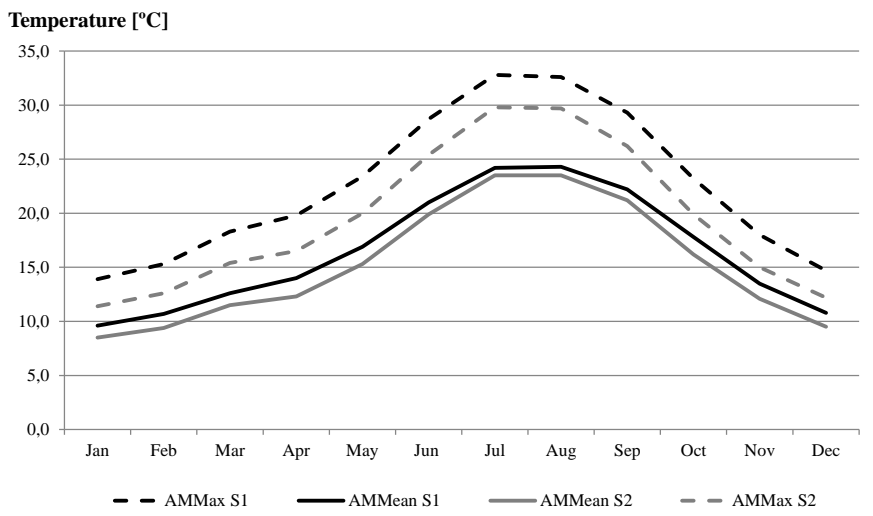

Fig. 2. S1 (Beja) and S2 (Portalegre): Average Monthly Maximum (AMMax) and Average Monthly Mean (AMMean) temperature.

The school in Beja was refurbished between October 2008 and September 2009 while the one in Portalegre was under rehabilitation works between September 2008 and June 2010. In both cases, the intervention included the refurbishment of the existing facilities as well as the construction of new buildings (e.g. new laboratories in S1 or the library building in S2).

Regarding the glazing, in S1 some frames were restored, but as a general approach, new aluminum framed double-glazed windows were placed in both schools.

In S1 three wall type solutions can be found:

a) Simple walls with no isolation (pre-existing $500 \mathrm{~mm}$ stone masonry walls, both faces covered with painted plaster);

b) Double layered masonry wall, with thermal isolation between layers (in the ventilated cavity);

c) Simple layered wall with continuous external thermal layer on the outside (60mm expanded polystyrene layer).

In S2, two main building solutions can be found:

a) pre-existing walls: thermal isolation placed on the inside type Pladur-Term $N$ (plasterboard walls reinforced with expanded polystyrene panel $10+40 \mathrm{~mm}$ ) over the existing exterior concrete/masonry wall;

b) new walls: exterior reinforced concrete wall, thermal isolation (50mm expanded polystyrene layer) and water repellent layer over thermal block (interior wall);

Regarding air conditioning and ventilation systems, in school S1 we can find a centralized cooling and heating system. Herein, the thermal output is accomplished using a vapourcompression heat pump. Moreover, each classroom is provided with an AHU.

In terms of thermal energy production, school S2 presents a decentralized strategy with the heat production units located on the roof of each building. The studied classroom in this school is placed in a building with a heat pump connected to air handling units (three AHUs serve 10 classrooms and one room for teachers).

The studied population was constituted by high school students, with uniform gender distribution. The two classrooms under study are south oriented. In S1 the classroom is located in the main classroom building (A) - a building formerly inaugurated in 1960, of a rectangular shape. The classroom in $\mathrm{S} 2$ is located in a quadrangular shaped building. In both cases, during our investigation, schools were working on "freerunning" conditions and only natural ventilation strategies were used to control Ta and IAQ. The main characteristics of the analyzed classrooms are presented in Table 1 and in Fig. 3.

\section{B. IEQ analysis-measurements in the classrooms}

Both IAQ and TC parameters, such as relative humidity (RH), air temperature and $\mathrm{CO}_{2}$ concentrations were monitored for two weeks, during the end of April and the first two weeks of May 2013. Different equipment was used to monitor all the parameters: the SD800 Datalogger by Extech, Tinytag Talk 2 and Tinytag Ultra 2 data-loggers. Because of regular class action, and considering students behavior, the equipment could not be placed in the middle of the room and was integrated in the room furniture, at a height of circa $0.6 \mathrm{~m}$ above the floor (near the breathing height for seated people) in S1 and over the suspended ceiling at $2.30 \mathrm{~m}$ in S2. All outdoor meteorological information was obtained in www.ipma.pt.

TABLE I

CLASSROOMS S1 \& S2 CHARACTERISTICS AND WINDOWS DIMENSION (SCHOOL 1 AND SCHOOL 2, RESPECTIVELY).

\begin{tabular}{|c|c|c|c|c|c|c|}
\hline Room / School & Area $\left(\mathbf{m}^{2}\right)$ & Ceiling (m) & Volume $\left(\mathbf{m}^{3}\right)$ & $\begin{array}{l}\text { Number of occupants } \\
\text { (during class period) }\end{array}$ & $\begin{array}{l}\text { Occupancy density } \\
\left(\text { pupil } / \mathbf{m}^{2}\right)\end{array}$ & $\begin{array}{l}\text { Window to } \\
\text { floor ratio }\end{array}$ \\
\hline$\overline{\text { S1 }}$ & 46.21 & 3.36 & 155.25 & 26 (median) & 0.57 & 0.19 \\
\hline \multirow[t]{2}{*}{$\mathbf{S 2}$} & 56.81 & 2.77 & 157.15 & 21 (dominant class) & 0.37 & 0.22 \\
\hline & & Height (m) & Width (m) & Area $\left(\mathrm{m}^{2}\right)$ & & Total Area $\left(\mathrm{m}^{2}\right) \mid\left(\mathrm{N}^{\mathrm{o}}\right.$ units $)$ \\
\hline \multirow{2}{*}{ S1 } & Window & 1.8 & 1.2 & 2.16 & & $8.64(4)$ \\
\hline & Window (opening) & 1.124 & 0.6 & 0.74 & & $2.98(4)$ \\
\hline \multirow{2}{*}{$\mathbf{S 2}$} & Window & 1.82 & 2.3 & 4.19 & & $12.56(3)$ \\
\hline & Window (opening) & 1.20 & 0.77 & 0.92 & & $2.73(3)$ \\
\hline
\end{tabular}



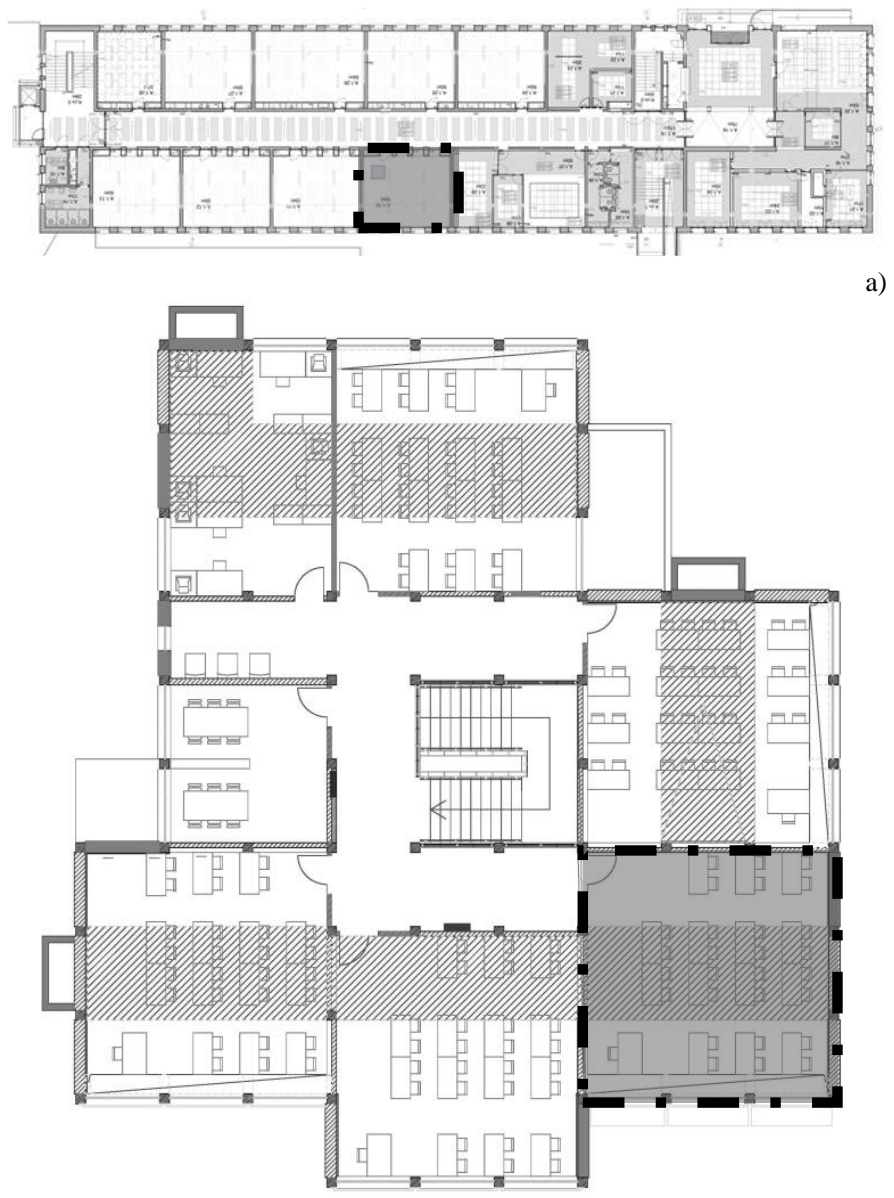

b)

Fig. 3. Level 1 plans of the schools and classroom location. a) S1 (Beja); b) S2 (Portalegre).

\section{IEQ subjective assessment}

A subjective assessment was done within the two monitored classrooms S1 and S2. This survey was specially developed for the assessment of IEQ in schools. It has been previously applied in an academic campus [13] and presented in [14].

Among the general information (age, gender, height, weight), students were asked to mark what they were wearing by means of a clothing check-list, so that the actual clothing level could be calculated [15]. The other questions concerned Thermal Comfort (TC), Indoor Air Quality (IAQ), Acoustic Comfort (AC) and Visual Comfort (VC).

The questionnaire was explained by the research team members, before being applied to 35 students (19 in S1 and 16 in S2) of the $10^{\text {th }}$ grade aged between $15-17$ years. For the present, only TC and IAQ questions are studied. Regarding TC, students gave a judgment on thermal acceptability, voted for thermal sensation (TSV) and thermal preference (TP). They were also questioned about draughts and air dryness, as well as about their preference of indoor air temperature control: "If you could control indoor air temperature, would you prefer: a) It varied in accordance with the external climate conditions; b) It was almost the same all year despite the external climate". For the indoor air quality vote (IAQ), the adopted parameters were the Air stiffness and Air smell followed by Air quality (Global assessment).

\section{RESULTS AND DISCUSSIONS}

During both monitoring periods, the exterior temperatures varied in Beja between $5^{\circ} \mathrm{C}-28.5^{\circ} \mathrm{C}$ and in Portalegre between $6.3{ }^{\circ} \mathrm{C}-30.8{ }^{\circ} \mathrm{C}$. From the monitoring indoors it was verified that during $50 \%$ of the monitored periods, in $\mathrm{S} 1$ the recorded values were out of the thermal comfort interval $\left(20-24^{\circ} \mathrm{C}\right)$, i.e. presented compliance values out of this interval; in S2 the noncompliance percentage was only of $22 \%$. During the defined occupancy periods (please see Table III), temperatures in S1 reached the lowest value of $17.4{ }^{\circ} \mathrm{C}$ and the maximum of 25.9 ${ }^{\circ} \mathrm{C}$. In S2, these values varied between $19.1^{\circ} \mathrm{C}$ and $26.5^{\circ} \mathrm{C}$.

The maximum recorded $\mathrm{CO}_{2}$ concentration was in both cases studies much above the recommended value in the current national legislation system (roughly saying, an average value of $1,250 \mathrm{ppm}$ during occupancy period) [16]. The lowest $\mathrm{CO}_{2}$ concentration values were recorded in both schools during unoccupied classrooms, as expected (after class period or at night, infiltration period).

As regards relative humidity $(\mathrm{RH})$, the recorded values during the occupancy time of the classrooms were within the recommended values, almost $100 \%$ of the time - only lowering to $61 \%$ compliance in S2 in one of the nine monitored periods - during this period $(\mathrm{X})$, the lowest registered value was 24.9 $\%$, slightly below the minimum reference value.

\section{A. Results from the objective assessment $S 1 \& S 2$}

Time evolution of indoor air temperature and $\mathrm{CO}_{2}$ concentration values in both case-studies are presented in Figure 4.a) and 4.b) - the occupancy periods are represented by the shadowed areas.

TABLE II

SYNTHESIS TABLE OF THE RECORDED VALUES IN S1 \& S2 DURING VARIOUS OCCUPANCY PERIODS

\begin{tabular}{|c|c|c|c|c|c|c|c|c|c|}
\hline \multirow{2}{*}{ Parameter } & \multicolumn{2}{|c|}{ Lowest record } & \multicolumn{2}{|c|}{ Highest record } & \multicolumn{2}{|c|}{ Average } & \multicolumn{2}{|c|}{ St. deviation } & \multirow{2}{*}{ Reference value } \\
\hline & $\overline{\mathrm{S} 1}$ & $\mathrm{~S} 2$ & $\mathrm{~S} 1$ & $\mathrm{~S} 2$ & $\mathrm{~S} 1$ & $\mathrm{~S} 2$ & S1 & S2 & \\
\hline Room temperature $\left({ }^{\circ} \mathrm{C}\right)$ & 17.4 & 19.1 & 25.9 & 26.5 & 21.6 & 23.2 & 2.1 & 1.5 & $20-24$ [17], [15] \\
\hline Relative Humidity (\%) & 26.9 & 24.9 & 65.9 & 57.8 & 49.3 & 42.2 & 8.5 & 8.0 & $30-70[17]$ \\
\hline Carbon dioxide (ppm) & 426 & 449 & 7,645 & 7,097 & 1,452 & 1,515 & 1,164 & 1,014 & $\leq 1,250[16]$ \\
\hline
\end{tabular}


TABLE III

THE PERCENTAGE OF COMPLIANCE FOR THE OCCUPANCY PERIODS IN S1 \& S2

\begin{tabular}{|c|c|c|c|c|c|c|c|c|c|c|c|}
\hline \multirow{2}{*}{\multicolumn{2}{|c|}{ Occupancy Period }} & \multicolumn{4}{|c|}{ Percentage of compliance S1 (\%) } & \multicolumn{4}{|c|}{ Percentage of compliance S2 (\%) } & \multicolumn{2}{|c|}{$\operatorname{Ext} \operatorname{Temp}\left({ }^{\circ} \mathrm{C}\right)^{*}$} \\
\hline & & \multirow{2}{*}{$\begin{array}{l}\text { Room S1 } \\
\text { [10:00 - 16:15] }\end{array}$} & \multirow{2}{*}{$\begin{array}{l}\text { Temp } \\
89.0\end{array}$} & \multirow{2}{*}{$\begin{array}{l}\text { RH } \\
100\end{array}$} & \multirow{2}{*}{$\begin{array}{l}\mathrm{CO}_{2} * * \\
0.0\end{array}$} & \multirow{2}{*}{$\begin{array}{l}\text { Room S2 } \\
-\end{array}$} & \multirow{2}{*}{$\begin{array}{l}\text { Temp } \\
-\end{array}$} & \multirow{2}{*}{$\begin{array}{l}\mathbf{R H} \\
-\end{array}$} & \multirow{2}{*}{$\begin{array}{l}\mathrm{CO}_{2} \\
-\end{array}$} & \multirow{2}{*}{$\begin{array}{l}\text { S1 } \\
14.4\end{array}$} & \multirow{2}{*}{$\begin{array}{l}\mathbf{S 2} \\
-\end{array}$} \\
\hline $\mathbf{I}$ & $30 / 04 / 2013$ & & & & & & & & & & \\
\hline II $* * *$ & $01 / 05 / 2013$ & {$[08: 15-16: 15]$} & 0.0 & 100 & 100 & - & - & - & - & 15.9 & - \\
\hline III & $02 / 05 / 2013$ & {$[08: 15-16: 15]$} & 63.5 & 100 & 7.3 & {$[12: 00-16: 05]$} & 100 & 100 & $\mathbf{0 . 0}$ & 20.2 & 21.4 \\
\hline IV & $03 / 05 / 2013$ & {$[08: 15-13: 30]$} & 76.8 & 100 & 34.3 & {$[08: 30-16: 05]$} & 100 & 100 & 41.2 & 22.4 & 22.6 \\
\hline $\mathbf{V}$ & $06 / 05 / 2013$ & {$[08: 15-17: 35]$} & 100 & 98.6 & 57.0 & {$[08: 30-16: 05]$} & 100 & 100 & 22.4 & 23.3 & 21.7 \\
\hline VI & $07 / 05 / 2013$ & {$[10: 00-16: 15]$} & 100 & 100 & 20.8 & {$[08: 30-16: 05]$} & 100 & 100 & 73.7 & 25.6 & 24.3 \\
\hline VII & $08 / 05 / 2013$ & {$[08: 15-16: 15]$} & 100 & 100 & 75.8 & {$[08: 30-13: 30]$} & 100 & 100 & 36.9 & 21.5 & 19.4 \\
\hline VIII & $09 / 05 / 2013$ & {$[08: 15-16: 15]$} & 100 & 100 & 100 & {$[08: 30-16: 05]$} & 100 & 100 & 38.6 & 24.0 & 19.2 \\
\hline IX & $10 / 05 / 2013$ & {$[08: 15-13: 30]$} & 100 & 100 & 41.6 & {$[08: 30-16: 05]$} & 100 & 100 & 100 & 22.6 & 22.1 \\
\hline $\mathbf{X}$ & $13 / 05 / 2013$ & {$[08: 15-17: 35]$} & 76.3 & 100 & 83.3 & {$[08: 30-16: 05]$} & 29.0 & 61.2 & 80.0 & 25.3 & 28.1 \\
\hline XI & $14 / 05 / 2013$ & - & - & & - & {$[08: 30-16: 05]$} & 26.7 & 100 & 67.2 & - & 21.7 \\
\hline
\end{tabular}

Note*: External temperature values correspond to the mean values registered during each of the occupancy periods.

Note**: the values of the $\mathrm{CO}_{2}$ compliance previously published in [10] relating S1 had been estimated according to the old national legislation [18].

The percentage herein presented has been calculated according to the December 2013 legislation [16], recently implemented.

Note***: $1^{\text {st }}$ May is a holiday in Portugal-Labor Day.
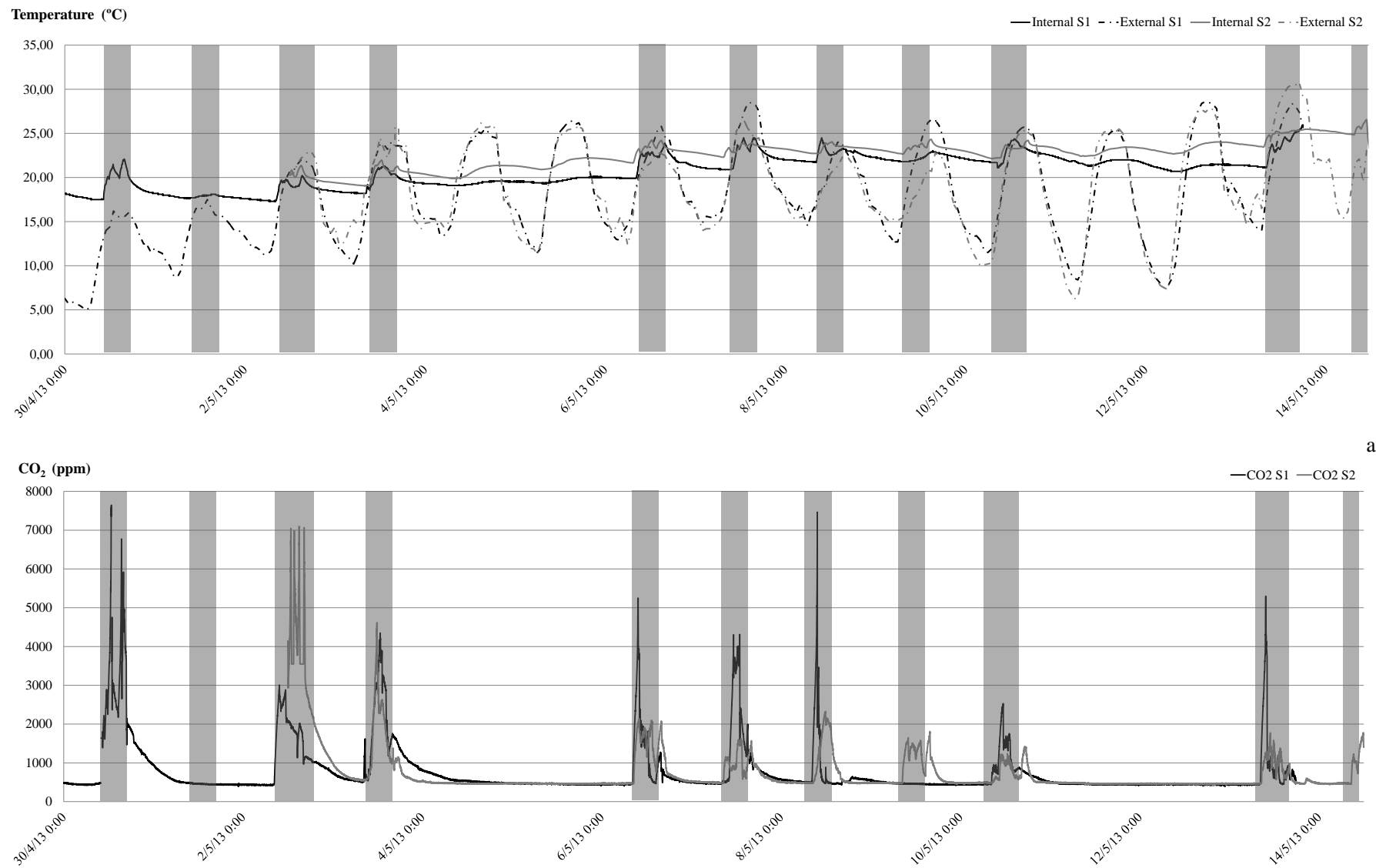

b)

Fig. 4. Graphical representation of the recorded values: a) Temperature values in room S1 and S2 between 30th April e 14th May 2013; b) CO 2 concentration values (the shadowed areas correspond to the ten occupancy periods, as defined in Table III). 
In S1 it was verified that only during $20 \%$ of the time (two monitored periods), the average Ta was out of the reference interval (periods II \& III, average Ta $=17.9^{\circ} \mathrm{C}$ and $19.2^{\circ} \mathrm{C}$ ). In terms of the maximum Ta values, the monitoring revealed that in $40 \%$ of the periods, the uttermost values of the interval were not respected (periods II, VI, VII \& IX, maximum registered Ta was $18.1^{\circ} \mathrm{C}, 24.5^{\circ} \mathrm{C}, 24.5^{\circ} \mathrm{C}$ and $25.9^{\circ} \mathrm{C}$, respectively).

Relating average Ta values in $\mathrm{S} 2$, the upper temperature reference value was not respected during the last two monitored periods, average $\mathrm{Ta}=25.1^{\circ} \mathrm{C}$ and $25.3^{\circ} \mathrm{C}$. Moreover, during $44.4 \%$ of the periods, the maximum Ta value was higher than $24^{\circ} \mathrm{C}$ (period V, VII, X and XI, maximum Ta achieved $24.2^{\circ} \mathrm{C}$, $24.3^{\circ} \mathrm{C}, 25.3^{\circ} \mathrm{C}$ and $26.3^{\circ} \mathrm{C}$, respectively).

In terms of $\mathrm{CO}_{2}$ concentration, during various occupancy periods the average values varied between 463-3,103 ppm in $\mathrm{S} 1$ and $856-4,360 \mathrm{ppm}$ in S2. These average values were respected around $40 \%$ of the periods both in S1 and S2. Nevertheless, only in one of the monitored periods (out of nine) did the average $\mathrm{CO}_{2}$ value in $\mathrm{S} 2$ go above 1,750,ppm, whilst in $\mathrm{S} 1$ this value was exceeded in $40 \%$ of the monitored periods. Concerning the maximum registered values, in S1 during $80 \%$ of the periods the maximum $\mathrm{CO}_{2}$ concentration was over 2,500 ppm and in $20 \%$ achieved values higher than 7,000 ppm. In S2, the opposite situation was verified - in $80 \%$ of the cases, the maximum $\mathrm{CO}_{2}$ value was below $2,500 \mathrm{ppm}$, only in one period it was slightly above 7,000 ppm.

\section{B. Results from the subjective assessment of $S 1 \& S 2$}

The questionnaires were conducted during the same day, on Monday, 15th May 2013, during the occupancy period X - as defined in Table III. In S2 it was distributed during the morning and in S1 during the afternoon. In both situations, students had been inside the room for more than $30 \mathrm{~min}$ - questionnaires were answered at the end of the class. Both classes answering the questionnaire were from the $10^{\text {th }}$ grade. Because two of the students were missing, only 19 answers were obtained in S1; in S2 only 16 out of 21 questionnaires were answered. The characteristics of the classes answering the questionnaire are synthesized in Table IV. Students' answers to the questionnaire regarding TC and IAQ are presented in Fig. 5 and Fig.6, respectively.

During the questionnaire, in $\mathrm{S} 1$ the classroom conditions were: $\mathrm{Ta}=25.2^{\circ} \mathrm{C}, \mathrm{RH}=41.4 \%$ and $\mathrm{CO}_{2}=753 \mathrm{ppm}$. Outdoor temperature was $28.1^{\circ} \mathrm{C}$; in $\mathrm{S} 2, \mathrm{Ta}=24.9^{\circ} \mathrm{C}, \mathrm{RH}=35.1 \%$ and $\mathrm{CO}_{2}=1,188 \mathrm{ppm}$. Outdoor temperature was $25.4{ }^{\circ} \mathrm{C}$. Herein, the answers to the first TC question - Do you consider the thermal environment condition acceptable? - were overwhelming: $94.7 \%$ of the students answered YES. Only 5.3 $\%$ disagreed.

TABLE IV

SUMMARIZING TABLE OF CHARACTERISTICS OF THE SURVEYED POPULATION

\begin{tabular}{|c|c|c|c|c|c|}
\hline $\begin{array}{l}\text { School/ } \\
\text { Class }\end{array}$ & No. Students & Age (y) & Height (m) & $\begin{array}{l}\text { BMI } \\
\left(\mathrm{kg} / \mathrm{m}^{2}\right)\end{array}$ & $\begin{array}{l}\text { Clo } \\
\text { (value } \pm \text { stdev) }\end{array}$ \\
\hline S1 & 19 & 15.6 & 1.64 & 21.7 & $0.45 \pm 0.04$ \\
\hline $\mathrm{S} 2$ & 16 & 15.5 & 1.68 & 20.7 & $0.55 \pm 0.14$ \\
\hline
\end{tabular}

Despite indoor $\mathrm{T}_{\mathrm{a}}=25.2{ }^{\circ} \mathrm{C}, 58 \%$ of the students stated they were feeling Neutral (of which 5\% curiously stated they did not accept the condition) and more than $35 \%$ of the students who stated feeling Slightly warm said they accepted their condition. The same goes for the $5 \%$ that stated feeling Warm.

In Fig. 5. a) the thermal preference is plotted along TSV. In classroom S1, TSV votes varied between 0 Neutral and +2 Warm. Despite $\mathrm{T}_{\mathrm{a}}=25.2^{\circ} \mathrm{C}$, no student stated preferring a Much cooler environment. A vast majority of the students, $84 \%$ voted for No change, although $32 \%$ of these indicated feeling Slightly warm. Only $10 \%$ stated they prefer A bit cooler, half of these stated feeling Neutral and other half stated feeling Slightly warm.

In $\mathrm{S} 2$, the thermal acceptability votes were not different from those in S1: $93.7 \%$ of the students answered $Y E S$, against $6.3 \%$ $\mathrm{No}$ answers - the negative votes corresponded to a thermal sensation vote of Warm. Nevertheless at $\mathrm{T}_{\mathrm{a}}=24.9{ }^{\circ} \mathrm{C}, 56 \%$ of the students stated feeling Neutral, $6 \%$ answered Slightly cool (but agreeing with their condition) and 38\% stated feeling Slightly warm or Warm.

From Fig. 5. b) it is verified that TSV votes varied between 1 Slightly Cool and +2 Warm. 64\% voted No change, although $6 \%$ of these stated feeling Slightly cool, $13 \%$ Slightly warm and $6 \% \mathrm{Warm}$. Interestingly, this confirms previous studies in the field - neutrality does not always correspond to the preferred thermal sensation. Moreover, $19 \%$ voted A bit warmer, even if stated feeling Neutral or Slightly warm. The $6 \%$ Much cooler votes correspond to Warm TSV.
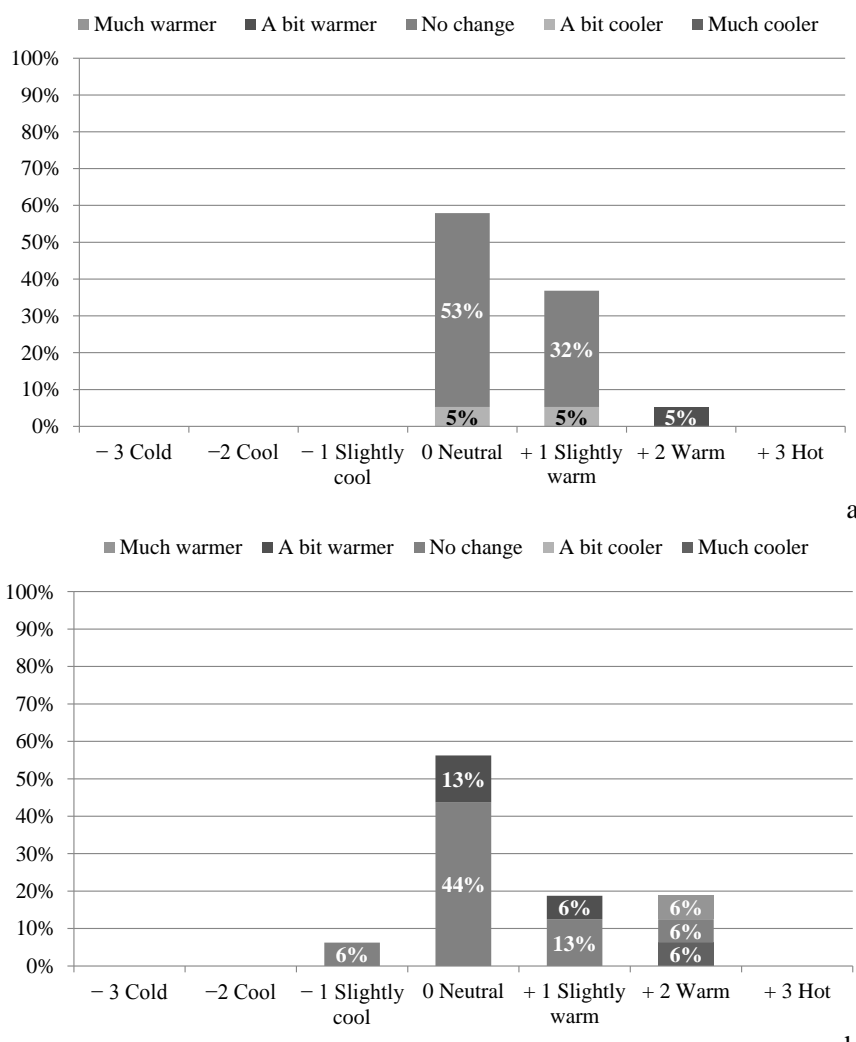

Fig. 5. Thermal sensation votes (answer to the question: How do you feel at this moment?) plotted with thermal preference votes (answer to the question: How would you like to feel?): a) S1; b) S2. 
Regarding indoor air temperature fluctuation, in S1 79\% of the students expressed preference for an environment in which temperature varied in accordance with the external climate conditions, rather than a "fixed temperature" independently of the external climate. The classroom in S2 revealed an even higher preference for non.-conditioned spaces, $94 \%$.

Concerning draughts and preference, in $\mathrm{S} 1$, a bit more than $40 \%$ stated feeling draughts, but only $13 \%$ of these stated feeling discomfort with this, while in S2 only 11\% feeling draughts, but no one stated feeling discomfort. In Fig. 6 a) and Fig.6 b), the subjective answers to Air stiffness (Clean Air /Polluted Air) and Air quality (Global assessment) in both schools are put side by side.

Concerning Air stiffness, in S1, more than $60 \%$ of the students voted between Slightly good and Good-Exceptional, circa $15 \%$ voted neutrally (Slightly bad - Slightly good) and around 20\% voted negatively (Bad and/or Slightly bad).
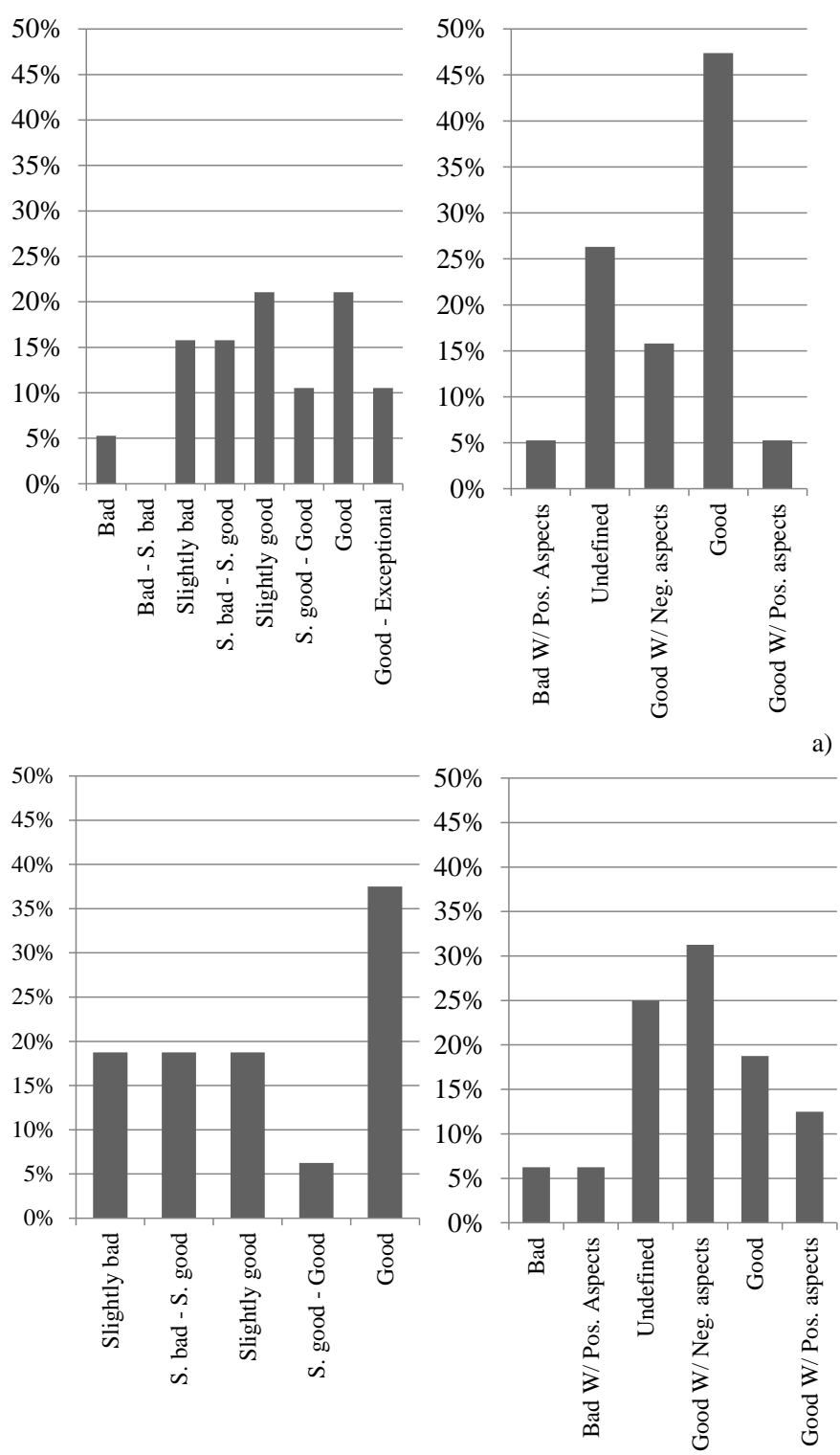

b)

Fig. 6. Air stiffness votes (Clean Air/Polluted Air) and General air quality votes: a) S1; b) S2.
The Air smell votes did not differ much from the Air stiffness. In $\mathrm{S} 2$, these votes were relatively the same i.e., almost $20 \%$ voted Slightly bad and other $20 \%$ Slightly bad-Slightly good, the remaining votes varied between Slightly good and Good. In this school, the Air smell votes differed significantly: $44 \%$ voted negatively, between Terrible and Slightly bad; $25 \%$ voted neutrally (Slightly bad - Slightly good) and the rest voted between Slightly good and Good.

Regarding the global quality air assessment, in S1 more than $25 \%$ of the students were unable to define their vote. Nevertheless, the results are rather positive - almost $70 \%$ of the votes varied between Good with negative aspects and Good with positive aspects (a vote closer to Exceptional), and only $5 \%$ of them are clearly negative - Bad with positive aspects. A similar percentage of Undefined votes was found in S2. Moreover, around 13\% voted negatively (Bad or Bad w/ Positive Aspects) but a significant majority, more than $60 \%$, varied their votes between Good with negative aspects and Good with positive aspects.

\section{Percentage of the dissatisfied based on $\mathrm{CO} 2$ concentration values}

In classroom $\mathrm{S} 1$, during the questionnaire, metered average indoor $\mathrm{CO}_{2}$ concentration value was $753 \mathrm{ppm}$. Plotting this value in the expression $\mathrm{PD}(\%)=395^{*} \mathrm{EXP}\left(-15.15^{*} \mathrm{CCO} 2^{\wedge}\right.$ 0.25) [19], where the $\mathrm{PD}$ is expressed in terms of $\mathrm{CO}_{2}$ concentration values in excess to outside air (ppm), circa $13 \%$ of the individuals would be dissatisfied within those conditions. In $\mathrm{S} 2$ the average concentration value of this pollutant was $1,188 \mathrm{ppm}$, herein, the expected $\mathrm{PD}=23 \%$. Outdoor $\mathrm{CO}_{2}$ concentration values were not measured, an estimated value of $380 \mathrm{ppm}$ was considered for this estimation.

\section{Discussion}

Assuming that none of the schools had the HVAC systems running, the analysis from the $\mathrm{CO}_{2}$ concentration values permit us stating that IAQ in S1 is a more prominent problem than in S2 when running in free-mode conditions - not only the maximum registered values were higher as, more importantly, the compliance percentage of this parameter was lower in the analyzed occupancy periods. This can be due to the lower average occupancy density registered in S2, but also due to occupants (both students and teachers) behavior - it should be noted that the window opening enhanced by each of the casement windows in S2 is bigger than the window opening allowed by each of the sliding windows in S1. In terms of air temperature (Ta), generally, S2 also "behaved" better than S1, with the exception of the two last monitored periods when the Ta was most of the time exceeded the maximum recommended value. Considering that external temperature did not vary much between municipalities, this can also be due to the glazing surfaces: classroom S2 glazing area facing south is $45 \%$ higher than $\mathrm{S} 1$ 's.

Concerning the subjective assessment, the TSV expressed in $\mathrm{S} 1\left(\mathrm{Ta}=25.2^{\circ} \mathrm{C}\right)$ questionnaires were expressed in the interval $[0 ; 2]$, while in classroom S2 $\left(\mathrm{Ta}=24.9^{\circ} \mathrm{C}\right)$, the TSV varied between $[-1 ; 2]$. It is significant that although Ta was close to $25^{\circ} \mathrm{C}$ in both cases, in both classes the acceptability vote was higher than $90 \%$. It is noteworthy that in S2 almost $20 \%$ of the 
students voted A bit warmer, even if stated feeling Neutral or Slightly warm, indicating a certain preference for warmer environments. These TSV reinforce that "people living in warm climates can more easily accept and work longer in hot environment than people from colder climates" [20].

Relating IAQ, the results from the subjective assessment did not differ much in both classrooms in terms of the Air stiffness and Air smell votes. General air quality votes distribution varied less in classroom S1. Nonetheless, in both cases, almost a quarter of the students were unable to express a defined vote. The PD obtained from the subjective assessment, correspondent to the negative votes obtained from the General air quality question, was in both cases much smaller than the one estimated in section $\mathrm{C}$ - these results confirm previous studies where the subjective assessment is made by "outsiders" and not by the actual occupants, whose vote was more "sensitive", i.e. not accommodated [21].

\section{CONCLUSIONS \& OUTLOOK}

On the basis of the results presented herein, collected during a "pre-cooling"/ mid-season in free-running conditions, it was confirmed that young students in the Mediterranean area feel comfortable under a wider range of temperature than those recommended by the norms. It also confirmed that thermal neutrality is not the preferred state. Interestingly, in both schools students expressed a significant preference for nonconditioned spaces, i.e. an environment in which temperature varied in accordance with the external climate conditions. These assumptions might, for instance, contribute to the resetting of temperature setting in HVAC building management systems and possibly contribute to energy costs reduction.

Concerning indoor air quality, focusing on $\mathrm{CO}_{2}$ concentration levels, the perceived votes reveal students' adaptation to the environment exposure. Even more concerning, it was found that IAQ regulations were not being observed. The concentration of this pollutant frequently exceeded the national and international reference limits - it is therefore imperative that when classrooms are running in free-mode, staff and teachers should be encouraged to promoting IAQ improvement by e.g. increasing air renewal during class break by window opening. In the present case, both classrooms are located above the pavement level for which no security question blocks the window opening procedure.

\section{ACKNOWLEDGMENTS}

The presented work is part of a wider research project, called Energy Efficient Schools (Escolas Energeticamente Eficientes, 3Es), granted by Teixeira Duarte in the framework of the Portuguese Program of R\&D Projects associated to Large Public Tenders. The authors are thankful to Parque Escolar E.P.E. for the provision of the database on the Portuguese secondary schools. The presented work is framed under the Energy for Sustainability Initiative of the University of Coimbra and LAETA (Associated Laboratory for Energy, Transports and Aeronautics) Project Pest E/EME/LA0022/2011 and was supported by the Foundation for Science and Technology under grant SFRH/BD/77105/2011.

\section{REFERENCES}

[1] A. Blyth, R. Almeida, D. Forrester, A. Gorey, and G. Hostens, "Modernising Secondary School Buildings in Portugal," 2012.

[2] M. Gameiro da Silva, C. H. Antunes, H. Bernardo, H. Jorge, L. Cruz, E. Barata, L. Dias Pereira, M. Coimbra, G. Luis, L. Neves, and J. Costa, "A preliminary assessment of energy performance in refurbished schools," in 1 st International Congress on Energy \& Environment (ICEE): bringing together Economics and Engineering, 2013, no. May.

[3] H. Bernardo and L. Dias Pereira, "An integrated approach for energy performance and indoor environmental quality assessment in school buildings - Green Brain of the Year Contest 2014 (Finalist)," 2014.

[4] Alfano, F. R. A. (ed.), L. Bellia, A. Boerstra, F. van Dijken, E. Ianniello, G. Lopardo, F. Minichiello, P. Romagnoni, and M. C. Gameiro da Silva, Indoor Environment and Energy Efficiency in Schools. Part 1: Principles. REHVA, Federation of European Heating and Air-conditioning Associations, 2010.

[5] M. Schneider, "National Clearinghouse for Educational Facilities," Building, vol. 75, pp. 2-19, 2002.

[6] L. Dias Pereira, M. Gameiro da Silva, and E. Cardoso, "Indoor air quality audit and evaluation on thermal comfort in a school in Portugal.," Indoor Built Environ., vol. Published, 2013.

[7] P. Wargocki and D. Wyon, "The Effects of Outdoor Air Supply Rate and Supply Air Filter Condition in Classrooms on the Performance of Schoolwork by Children (RP-1257)," HVAC\&R Res., vol. 13, no. 2, pp. 165-191, Mar. 2007. http://dx.doi.org/10.1080/10789669.2007.10390950

[8] Z. Bakó-Biró, D. J. Clements-Croome, N. Kochhar, H. B. Awbi, and M. J. Williams, "Ventilation rates in schools and pupils' performance," Build. Environ., vol. 48, pp. 1-9, Feb. 2011.

[9] “http://www.3es.pt/," 2013. [Online]. Available: http://www.3es.pt/.

[10] L. Dias Pereira, D. Raimondo, S. P. Corgnati, and M. Gameiro da Silva, "Assessment of indoor air quality and thermal comfort in Portuguese secondary classrooms: methodology and results," Build. Environ., vol. 81, pp. 69-80, 2014. http://dx.doi.org/10.1016/j.buildenv.2014.06.008

[11] Despacho no. 15793-F/2013, "Despacho no. 15793-F/2013 (in Portuguese - following the Decree-Law no 118/2013, publishes the parameters for the climatic zoning and respective data)." pp. $35088-(26-31), 2013$.

[12] SCE, "Decree-Law no. 118/2013. (2013). Regulation for the Energy Certification of Buildings (in Portuguese: Sistema Certificação Energética dos Edifícios (SCE)), Official Gazette of the Portuguese Republic, Series 1, No. 159.” 2013.

[13] P. M. de Carvalho, M. Gameiro da Silva, and J. Esteves, "Interrelations of Different Comfort Vote Parameters , Individual State of Mind and Subjective Assessment of Indoor Environment," in Clima 2013, 2013.

[14] P. M. de Carvalho, M. Gameiro da Silva, and J. Esteves, "Influence of weather and indoor climate on clothing of occupants in naturally ventilated school buildings," Build. Environ., vol. 59, pp. 38-46, 2013. http://dx.doi.org/10.1016/j.buildenv.2012.08.005

[15] ISO7730, "EN ISO 7730: 2005 Ergonomics of the thermal environment. Analytical determination and interpretation of thermal comfort using calculation of the PMV and PPD indices and local thermal comfort criteria." International Standardisation Organisation, Geneve, 2005.

[16] Portaria n. ${ }^{\circ}$ 353-A/2013, "Portaria n. ${ }^{\circ}$ 353-A/2013 (in Portuguese: Regulamento de Desempenho Energético dos Edifícios de Comércio e Serviços (RECS) - Requisitos de Ventilação e Qualidade do Ar Interior)." 2013.

[17] CEN, "EN 15251:2007 Indoor Environmental Input Parameters for Design and Assessment of Energy Performance of Buildings 
Addressing Indoor Air Quality, Thermal Environment, Lighting and Acoustics." CEN (European Committee for Standardization), Brussels, 2007.

[18] RSECE, "Decree-Law no. 79/2006. (2006). Regulation for the energy and HVAC systems in buildings (in Portuguese: Regulamento dos Sistemas Energéticos de Climatização em Edifícios - RSECE), Official Gazette of the Portuguese Republic, Series A, No. 67." 2006.

[19] M. C. Gameiro da Silva, "Requisitos de Ventilação em Edifícios Escolares - Parecer técnico elaborado para Parque Escolar EPE.," ADAI, Departamento de Engenharia Mecânica da Universidade de Coimbra, 2009.

[20] S. P. Corgnati, M. Gameiro da Silva, R. Ansaldi, E. Asadi, J. J. Costa, M. Filippi, J. Kaczmarcczyk, A. K. Melikov, B. W. Olesen, Z. Popiolek, and P. Wargocki, REHVA - Indoor Climate Quality Assessment. REHVA, 2011, 2011, pp. 1-118.

[21] E. Cardoso, "Avaliação do Potencial de Utilização da Ventilação Natural em Edifícios Escolares," Internship Report, Ordem dos Engenheiros, Coimbra, 2012. 